\title{
ANALISIS PERSAINGAN PERBANKAN DENGAN GAME THEORY SERTA UPAYA MENINGKATKAN KEPUASAN NASABAH DENGAN PENDEKATAN IMPORTANCE PERFORMANCE ANALYSIS
}

\author{
Farid Juliyanto dan Evi Yuliawati Sari \\ Program Studi Teknik Industri, Institut Teknologi Adhi Tama Surabaya \\ e-mail: farid.juliyanto@gmail.com
}

\begin{abstract}
ABSTRAK
Kepuasan nasabah merupakan tujuan utama dari setiap perusahaan perbankan yang menjadi kunci utama dalam mempertahankan keberadaan industri perbankan. Tujuan penelitian ini adalah membandingkan antara Bank $Y$ dan Bank X pada sisi kualitas layanannya. Pada tahap pertama digunakan metode Game Theory untuk mengetahui pihak mana yang lebih unggul. Pada persaingan ini, Bank Y menggunakan 11 strategi dan Bank X menggunakan 10 strategi. Nilai yang diperoleh pada metode Game Theory ialah 0.14 artinya kemenangan untuk pemain baris yaitu Bank X. Tahap kedua ialah dengan mengidentifikasi atribut-atribut yang ada pada setiap layanan pihak yang kalah dalam hal ini ialah Bank Y. Kemudian digunakan metode Importance Performance Analysis untuk mengetahui prioritas perbaikan dari 25 atribut yang digunakan. Atribut yang menjadi prioritas perbaikan manajemen Bank Y untuk dapat bersaing dengan Bank X adalah (1) Desain Automatic Teller Machine multifungsi (setor dan tarik). (2) Isi surat perjanjian yang jelas dan mudah dimengerti. (3) Jumlah merchant yang mendukung layanan Bank. (4) Kepedulian perusahaan membimbing nasabah dalam berinvestasi.
\end{abstract}

Kata Kunci: Game Theory, Importance Performance Analysis, Kepuasan Pelanggan, Perbankan

\begin{abstract}
Customer's satisfaction is the main goal for any banking company and is the primary key to maintain the existence of banking industry. This research had the aim to make comparison between Bank $Y$ and Bank X. In the first phase, Game Theory method was used to find out which bank was superior in the service quality. In this competition Bank $Y$ utilized 11 strategies and Bank $X$ applied 10 strategies. The result obtained by the Game Theory method was 0.14, which mean that Bank $X$ was more superior in service. The second phase was to identify the existing attributes at each losing party's service, in this case, Bank Y. Then the importance performance analysis method was applied to know the improvement priority of 25 attributes used. The management improvement priority attributes of Bank $Y$ to compete with Bank X were: (1) Multifunction ATM (deposit and draw), (2) Lucid agreement letter and easy to understand, (3) The amount of merchants supporting the bank service, (4) Company concern to guide and conduct the customers to invest.
\end{abstract}

Keywords: Banking, Customer Satisfaction, Game Theory, Importance Performance Analysis

\section{PENDAHULUAN}

Kepuasan pelanggan adalah tingkat perasaaan seseorang setelah membandingkan kinerja (atau hasil) yang dirasakan dibandingkan dengan harapannya, [1]. Kepuasan pelanggan dapat memberikan manfaat antara lain: (1) hubungan antara perusahaan dengan konsumen menjadi harmonis, (2) memberikan dasar yang baik bagi pembelian uang (3) dapat mendorong terjadinya loyalitas, (4) membentuk suatu rekomendasi dari mulut ke mulut yang menguntungkan perusahaan, (5) reputasi perusahaan menjadi baik dimata pelanggan, (6) laba yang diperoleh dapat meningkat. Kepuasan konsumen bersifat dinamis dan relatif [2].

Menurut para akademisi, kepuasan pelanggan ialah konstruk yang berdiri sendiri dan dipengaruhi oleh kualitas layanan, [3]. Kualitas layanan juga dapat mempengaruhi loyalitas pelanggan secara langsung dan mempengaruhi loyalitas pelanggan secara tidak langsung melalui kepuasan, [4]. Berdasarkan data Badan Pusat Statistik pada tahun 2010 jumlah penduduk Indonesia tercatat sebanyak 237,6 juta orang. Jumlah tersebut merupakan pasar potensial yang sangat menjanjikan bagi investor. Sehingga iklim investasi di Indonesia diperkirakan akan selalu meningkat tiap 
tahunnya. Secara tidak langsung akan mempengaruhi sektor perekonomian Indonesia.

Sebuah artikel yang dirilis oleh kompas.com pada tahun 2015 menempatkan Bank Y sebagai Bank plat merah dengan asset tertinggi yakni sebesar Rp 905.76 triliun dan Bank X sebagai bank swasta dengan asset tertingi yakni Rp 584.44 triliun. Penelitian ini difokuskan pada Bank BUMN dengan asset tertinggi dan BUMS dengan asset tertinggi. Adapun obyek penelitian utuk BUMN adalah Bank Y dengan total asset Rp 905,76 trilliun dan untuk BUMS adalah Bank $\mathrm{X}$ dengan total asset sebesar $\mathrm{Rp}$ 584,44 trilliun.

Teori permainan merupakan suatu model matematika yang digunakan dalam situasi konflik atau persaingan antara berbagai kepentingan yang saling berhadapan sebagai pesaing [5]. Dengan menggunakan ServQual kemudian digunakan metode Importance performance analysis untuk memetakan atributatribut yang perlu diperbaiki guna meningkatkan kualitas layanan penyedia jasa dalam hal ini ialah Bank.

Adapun rumusan masalah dalam penelitian ini adalah: (1) bagaimana menentukan peyedia jasa perbankan terbaik dengan strategi layanan yang ditawarkan kepada nasabah? (2) Bagaimana mengidentifikasi kelemahan strategi layanan penyedia jasa perbankan? (3) Bagaimana rekomendasi yang dapat diberikan kepada pihak manajemen perbankan terhadap kelemahan yang teridentifikasi?

Batasan masalah dan asumsi dalam penelitian ini adalah: (1) Penelitian dilakukan pada Bank Yi Surabaya dan Bank X Surabaya. (2) Responden penelitian ialah nasabah Bank Y dan Bank X kota Surabaya. (3) Pengambilan data dilakukan pada bulan Februari-Maret 2017. (4) Penilaian kualitas layanan berdasarkan atribut-atribut yang diperoleh dari penyebaran Kuesioner. (5) Penelitian hanya berfokus pada gap 5, yakni kesenjangan antara persepsi nasabah dengan ekspektasi nasabah. (6) Responden memahami Kuesioner dan sesuai dengan yang diharapkan peneliti. (7) Responden mengetahui secara pasti layanan yang ditawarkan oleh pihak Bank. (8) Selama penelitian tidak ada kebijakan pemerintah yang dapat mempengaruhi kinerja perbankan. (9) Tidak terjadi bencana yang dapat mempengaruhi transaksi keuangan

Kepuasan pelanggan adalah tingkat perasaaan seseorang setelah membandingkan kinerja (atau hasil) yang dirasakan dibandingkan dengan harapannya [1]. Dapat dikatakan bahwa kepuasan pelanggan merupakan perasaan seseorang atas kinerja suatu produk yang diterima dibandingkan dengan harapannya setelah menggunakan suatu produk atau jasa.

Tjiptono mengatakan dengan adanya kepuasan pelanggan akan memberikan dampak pada produsen. Secara tidak langsung kepuasan pelanggan akan memberikan manfaat sebagai berikut: (1) Hubungan antara perusahaan dan para pelanggan menjadi harmonis. (2) Memberikan dasar yang baik bagi pembelian ulang. (3) Dapat mendorong terciptanya loyalitas pelanggan. (4) Membentuk suatu rekomendasi dari mulut ke mulut (mouth to mouth) yang menguntungkan bagi perusahaan. (5) Reputasi perusahaan menjadi baik di mata pelanggan. (6) Laba yang diperoleh dapat meningkat [6].

Tjiptono mengemukaan satu hal yang perlu diperhatikan disini adalah bahwa kepuasan pelanggan merupakan strategi yang dapat dipadukan untuk meraih dan meningkatkan kepuasan pelanggan, diantaranya Relationship Marketing, Superior Customer Service, Unconditional Guarantees, dan penanganan keluhan pelanggan. Sehingga dalam realisasinya perlu strategi yang sesuai dengan penyedia jasa, sehingga strategi yang digunakan akan mendorong kepuasan pelanggan [7].

Wyckof mendefinisikan kualitas pelayanan sebagai tingkat keunggulan yang diharapkan dan pengendalian atas tingkat keunggulan tersebut untuk memenuhi keinginan pelanggan [10]. Lewis \& Booms mendefinisikan kualitas pelayanan secara sederhana, yaitu ukuran seberapa bagus tingkat layanan yang diberikan mampu sesuai dengan ekspektasi pelanggan [8].

Zheithaml, et al. menyederhanakan sepuluh dimensi di atas menjadi lima dimensi pokok yang dikenal dengan SERVQUAL 
(service quality) yang terdiri dari: Bukti fisik (tangibles), Keandalan (reliability), Daya tanggap (responsiveness), Jaminan (assurance), dan Empati (emphaty) [9].

Zeithaml, et al. mengidentifikasi 5 (lima) kesenjangan yang menyebabkan kegagalan penyampaian jasa. Adapun kesenjangan tersebut adalah sebagai berikut: (1) Kesenjangan antara harapan konsumen dan persepsi manajemen. Manajemen tidak selalu memahami secara tepat apa yang diinginkan pelanggan (gap 1). (2) Kesenjangan antara persepsi manajemen dan spesifikasi kualitas asa. Manajemen mungkin memahami secara tepat geininan pelanggan, tetapi tidak menetapkan suatu set standar kinerja spesifik (gap 2). (3) Kesenjangan antara spesifikasi kualitas jasa dan penyampaian jasa. Para personel mungkin kurang terlatih atau tidak mampu atau tidak memnuhi standar yang telah ditetapkan. Atau bahkan mereka dihadapkan pada standar yg berlawanan (gap 3). (4) Kesenjangan antara penyampaian jasa dan komunikasi eksternal. Harapan konsumen dipengaruhi oleh pernyataan yang dibuat para wakil perusahaandan iklan perusahaan (gap 4). (5) Kesenjangan antara jasa yang dialami dan jas yang diharapkan. Kesenjangan ini terjadi bila memiliki persepsi yang keliru tentang kualitas jasa tersebut (gap 5) [10].

Bank adalah badan usaha yang kekayaannya terutama dalam bentuk aset keuangan (financial assets) serta bermotif profit juga sosial, jadi bukan hanya mencari keuntungan saja [11]. Nasabah merupakan konsumen dari pelayanan jasa perbankan [14]. Sehingga Nasabah dapat dikatakan sebagai pelanggan atau konsumen dari jasa perbankan.

Teori permainan (game theory) adalah bagian dari ilmu pengetahuan yang berkaitan dengan pembuatan keputusan pada saat ada dua pihak atau lebih berada dalam kondisi persaingan atau konflik [12]. Game theory merupakan suatu pendekatan matematis untuk merumuskan situasi persaingan dan konflik antara berbagai kepentingan [13].

Terdapat dua jenis strategi permainan yang dapat digunakan pada game theory, yaitu pure strategy (setiap pemain mempergunakan strategi tunggal) dan mixed strategy (setiap pemain menggunakan campuran dari berbagai strategi yang berbeda-beda). Pure strategy digunakan untuk jenis permainan yang hasil optimalnya mempunyai saddle point (semacam titik keseimbangan antara nilai permainan kedua pemain). Sedangkan mixed strategy digunakan untuk mencari solusi optimal dari kasus game theory yang tidak mempunyai saddle point.

Importance Performance Analysis (IPA) adalah suatu rangkaian atribut layanan yang berkaitan dengan layanan khusus dievaluasi berdasarkan tingkat kepentingan masing-masing atribut menurut konsumen dan bagaimana layanan dipersepsikan kinerjanya relatif terhadap masing-masing atribut. Analisis ini digunakan untuk membandingkan antara penilaian konsumen terhadap tingkat kepentingan dari kualitas layanan (importance) dengan tingkat kinerja kualitas layanan (performance).

Rata-rata hasil penilaian keseluruhan konsumen kemudian digambarkan ke dalam Importance-Performance Matrix atau sering disebut Diagram Kartesius, dengan sumbu absis (X) adalah tingkat kinerja dan sumbu ordinat (Y) adalah tingkat kepentingan.

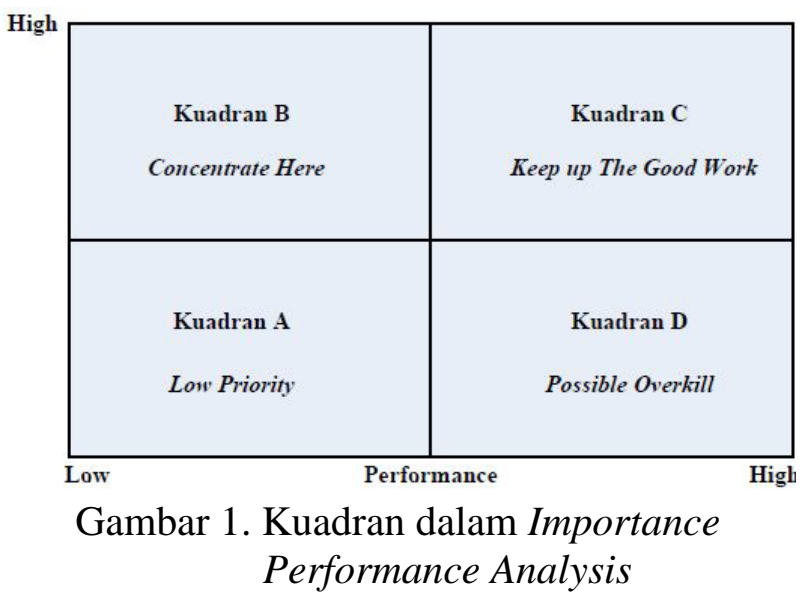

Karena populasi tak terhingga (tidak diketahui), maka untuk menentukan sampel minimum dari suatu populasi dapat menggunakan rumus Bernoulli dengan asumsi bahwa populasi berdistribusi normal.

$n=\frac{Z_{\frac{\alpha}{2}}^{2} \times p \times q}{e^{2}}$ 
Reliabilitas berkenaan dengan tingkat keajegan atau ketetapan hasil pengukuran, (Sukmadinata, 2009) [14]. Kuesioner dikatakan reliabel jika dapat memberikan hasil relatif sama (ajeg) pada saat dilakukan pengukuran kembali pada obyek yang berlainan pada waktu yang berbeda atau memberikan hasil yang tetap. Uji reliabilitas dilakukan dengan rumus cronbach alpha sebagai berikut:

$\alpha=\left[\frac{k}{k-1}\right]\left[1-\frac{\sum \sigma_{b}^{2}}{\sigma_{t}^{2}}\right]$

Apabila koefisien Cronbach Alpha $\left(\mathrm{r}_{11}\right) \geq$ 0,7 maka dapat dikatakan instrumen tersebut reliabel (Johnson \& Christensen, 2012) [15].

Ghozali (2009) menyatakan bahwa uji validitas digunakan untuk mengukur sah, atau valid tidaknya suatu kuesioner. Suatu kuesioner dikatakan valid jika pertanyaan pada kuesioner mampu untuk mengungkapkan sesuatu yang akan diukur oleh kuesioner tersebut [16].

$r_{x y}=\frac{N \sum X Y-\left(\sum X\right)\left(\sum Y\right)}{\sqrt{\left\{N \sum X^{2}-\left(\sum X\right)^{2}\right\}\left\{N \sum Y^{2}-\left(\sum Y\right)^{2}\right\}}}$

\section{METODOLOGI PENELITIAN}

Pada bagian ini akan dibahas tentang langkah-langkah dalam melakukan penelitan. Adapun langkah-langkah tersebut dikelompokkan menjadi 4 (empat) tahapan sebagai berikut: identifikasi masalah (latar belakang, rumusan, dan batasan asumsi), pengumpulan data (kuesioner terbuka tentang jenis layanan, kuesioner kualitas layanan, serta kuesioner kepentingan dan kinerja bank), pengolahan data (Game Theory, uji validitas dan reliabilitas, Importance Performance Analysis) dan analisa dan kesimpulan

\section{HASIL DAN PEMBAHASAN}

$\mathrm{X}$ secara resmi berdiri pada tanggal 21 Februari 1957 dengan nama Bank X. Pada tahun 2015 Bank X memiliki asset sebesar Rp 584,44 triliun dan merupakan satu-satunya bank swasta di Indonesia yang mampu bersaing di 3 besar bank dengan asset terbesar. Bank Y berdiri pada tanggal 2 Oktober 1998 sebagai bagian dari program restrukturisasi perbankan yang dilaksanakan oleh Pemerintah Indonesia.
Pada bulan Juli 1999, empat Bank milik Pemerintah digabungkan menjadi Bank Y. Bank Y merupakan Bank dengan asset tertinggi di Indonesia yakni sebesar Rp 905,76 triliun. Selanjutnya dilakukan penyebaran kuesioner terhadap 30 responden dari masing-masing bank untuk mengumpulkan informasi yang berkaitan dengan kualitas layanan masingmasing bank. Pada Tabel 1 dapat dilihat hasil rekapitulasi kuesioner terbuka yang nantinya digunakan sebagai strategi masing-masing bank.

\begin{tabular}{clc} 
Tabel & 1. Rekapitulasi Kuisioner & Terbuka \\
\hline No & \multicolumn{1}{c}{ Produk Bank X } & Total \\
\hline 1 & Produk Simpanan & 30 \\
2 & Perbankan Elektronik & 30 \\
3 & Produk X Mobile & 19 \\
4 & Kartu Kredit & 24 \\
5 & Produk Kredit Konsumen & 19 \\
6 & Produk Bancassurance & 14 \\
7 & Call Center & 13 \\
8 & Produk Remmitance & 30 \\
9 & Reksadana & 6 \\
10 & Jejaring Sosial X & 17 \\
\hline & & \\
\hline No & & Produk Bank Y \\
\hline 1 & Y Tabungan & 30 \\
2 & Y Debit & 30 \\
3 & Y E-Cash & 30 \\
4 & Y E-Money & 22 \\
5 & Y Kartu Kredit & 15 \\
6 & Y Kredit Konsumer & 15 \\
7 & Y Prioritas & 5 \\
8 & Y Produk Investasi & 16 \\
9 & Produk Bancassurance & 18 \\
10 & Jejaring Sosial Y & 18 \\
11 & Produk Remmitance & 30 \\
\hline & &
\end{tabular}

Dengan menggunakan data pada Tabel 1, kemudian dilakukan penyebaran kuesioner tertutup terhadap 50 nasabah pada masingmasing bank. Sebelum dilakukan rekapitulasi kuesioner terlebih dahulu dilakukan penyortiran pada kuesioner. Kuesioner yang rusak dan tidak lengkap tidak dapat digunakan sebagai data atau dianggap rusak. Dari 50 kuesioner yang telah disebar terdapat 1 (satu) buah kuesioner yang pengisiannya tidak lengkap sehingga dianggap rusak dan hanya terdapat 49 kuesioner yang digunakan. Untuk memastikan jumlah kecukupan sampel yang digunakan maka digunakan rumus Bernouli sebagai berikut: 
$n=\frac{z_{\alpha / 2}^{2} \times p \times q}{e^{2}}$

$n=\frac{1.96^{2} \times \frac{49}{50} \times \frac{1}{50}}{0,05^{2}}$

$n=30,118 \approx 31$ sampel

Tabel 2. Rekapitulasi Kuesioner Kualitas Layanan

\begin{tabular}{clc}
\hline & \multicolumn{1}{c}{ Produk X } & $\begin{array}{c}\text { Rata- } \\
\text { rata }\end{array}$ \\
\hline No & \multicolumn{1}{c}{4,43} \\
1 & Produk Simpanan & 4,58 \\
2 & Perbankan Elektronik & 4 \\
3 & Produk X Mobile & 3,97 \\
4 & Kartu Kredit & 3,4 \\
5 & Produk Kredit Konsumen & 3,28 \\
6 & Produk Bancassurance & 4,11 \\
7 & Call Center & 4,45 \\
8 & Produk Remmitance & 3,9 \\
9 & Reksadana & 3,54 \\
10 & Jejaring Sosial X & \\
\hline & & Rata- \\
\hline \multirow{2}{*}{ No } & & rata \\
& \multicolumn{1}{c}{ Produk Y } & 4,3 \\
1 & Y Tabungan & 3,8 \\
2 & Y Debit & 4,2 \\
3 & Y E-Cash & 4,2 \\
4 & Y E-Money & 4,02 \\
5 & Y Kartu Kredit & 4,1 \\
6 & Y Kredit Konsumer & 4,52 \\
7 & Y Prioritas & 3,9 \\
8 & Y Produk Investasi & 4,02 \\
9 & Produk Bancassurance & 3,7 \\
10 & Jejaring Sosial Y &
\end{tabular}

Dengan demikian maka sampel minimum sudah terpenuhi, sehingga data kuesioner dapat digunakan.

Pada Tabel 2 merupakan hasil rekapitulasi kuesioner tertutup yang nantinya akan digunakan sebagai input metode Game Theory. Dalam penentuan nilai yang digunakan ialah rata-rata dari tiap-tiap strategi yang digunakan oleh kedua belah pihak bank.

Dari data pada Tabel 2 kemudian dimasukan kedalam matri payoff untuk selanjutnya dilakkan perhitungan dengan menggunakan Game Theory. Pada Tabel 3 merupakan hasil perhitungan matrik payoff Bank X vs Bank Y. Adapun untuk menentukan matrik payoff digunakan rumus sebagai berikut:

$X_{i} Y_{j}=$ Strategi $_{i}$ Pemain Baris - Strategi $_{j}$ Pemain Kolom

Nilai maximin pada matrik tersebut adalah 0,13 , sedangkan nilai minimax adalah 0,14 , karena maximin dan minimax nilainya tidak sama, maka permainan ini diselesaikan dengan menggunakan metode programa linier. Metode Dual Simpleks memungkinkan untuk menggunakan strategi dari dua belah pihak.

Pada Gambar 2 Dapat dilihat bahwa nilai permainan adalah 0,14 , artinya kemenangan bagi pemain baris. Untuk mempermudah perhitungan, maka digunakan software POM QM for Windows, sehingga hasil yang diperoleh adalah seperti Tabel 3.

Dengan kata lain pada permainan ini dimenangkan oleh Bank X. Sesuai dengan tujuan diawal penelitian, pemain yang kalah akan diidentifikasi faktor-faktor yang dapat menyebabkan kekalahan pada pemain tersebut. Pada Gambar 2 memperlihatkan bahwa pemain baris (X) menggunakan 95\% strategi $\mathrm{X}_{1}$

\begin{tabular}{|l|r|r|r|r|r|r|r|r|r|r|r|r|}
\hline & Y 1 & Y 2 & Y 3 & Y 4 & Y 5 & Y 6 & Y 7 & Y 8 & Y 9 & Y 10 & $\begin{array}{r}\text { Y 11 } \\
\text { Row } \\
\text { Mix }\end{array}$ \\
\hline X 1 &, 13 &, 63 &, 23 &, 23 &, 41 &, 33 &, 14 &, 53 &, 41 &, 73 &, 13 &, 95 \\
\hline X 2 &, 28 &, 78 &, 38 &, 38 &, 56 &, 48 &, 1 &, 68 &, 56 &, 88 &, 28 &, 05 \\
\hline X 3 &,- 3 &, 2 &,- 2 &,- 2 &,- 02 &,- 1 &,- 32 &, 1 &,- 02 &, 3 &,- 03 & 0 \\
\hline X 4 &,- 33 &,- 17 &,- 23 &,- 23 &,- 05 &,- 13 &,- 35 &, 07 &,- 05 &, 27 &,- 33 & 0 \\
\hline X 5 &,- 9 &,- 4 &,- 8 &,- 8 &,- 62 &,- 7 &,- 92 &,- 5 &,- 62 &,- 3 &,- 9 & 0 \\
\hline X 6 & $-1,02$ &,- 52 &,- 92 &,- 92 &,- 74 &,- 82 & $-1,04$ &,- 62 &,- 74 &,- 42 & $-1,02$ & 0 \\
\hline X 7 &,- 19 &, 31 &,- 09 &,- 09 &, 09 & 0 &,- 21 &, 21 &, 09 &, 41 &,- 19 & 0 \\
\hline X 8 &, 15 &, 65 &, 25 &, 25 &, 43 &, 35 &, 1 &, 55 &, 43 &, 75 &, 15 & 0 \\
\hline X 9 &,- 4 &, 1 &,- 3 &,- 3 &,- 12 &,- 2 &,- 42 & 0 &,- 12 &,- 2 &,- 4 & 0 \\
\hline X 10 &,- 78 &,- 26 &,- 66 &,- 66 &,- 48 &,- 56 &,- 78 &,- 36 &,- 48 &,- 16 &,- 76 & \\
\hline Column Mix --> &, 21 & 0 & 0 & 0 & 0 & 0 &, 79 & 0 & 0 & 0 & 0 & \\
\hline & & & & & & & & & & & & \\
\hline Value of game (to row) &, 14 & & & & & & & & & & & \\
\hline
\end{tabular}

Gambar 2. Hasil Algoritma Software POM QM 
(Produk Simpanan) dan 5\% strategi $\mathrm{X}_{2}$ (Perbankan Elektronik) melawan pemain kolom (Bank Y) menggunakan 21\% strategi $\mathrm{Y}_{1}(\mathrm{Y}$ Tabungan) dan $79 \%$ strategi $\mathrm{Y}_{7}$ (Y Prioritas) untuk memenangkan permainan sebesar $14 \%$.

Selanjutnya merupakan Kuesioner identifikasi dimensi kualitas jasa terhadap jenis layanan jasa Bank. Kuesioner ketiga (tertutup) digunakan untuk mengetahui seberapa jauh jasa yang ditawarkan oleh pihak bank merupakan jasa yang dibutuhkan oleh nasabah (tingkat kepentingan) dibandingkan dengan pelayanan yang telah diterima oleh nasabah.

Atribut yang tersusun pada Tabel 3 merupakan hasil pengelompokan berdasarkan dimensi kualitas jasa. Adapun dimensi kualitas yang digunakan ialah Tangibles, Responsiveness, Reliability, Assurance, dan emphaty dan pengelompokannya berdasarkan strategi yang digunakan pada Game Theory. Setelah diketahui pemenang pada tahapan Game Theory, kemudian dilakukan rekaitulasi kuesioner 3 untuk mengetahui tingkat kepentingan dan persepsi nasabah terhadap layanan yang ditawarkan oleh penyedia jasa, dalam hal ini adalah Bank.

Sebelum data pada Tabel 4 digunakan maka perlu dilakukan pengujian terhadap data tersebut, apakah data tersebut Reliable dan Valid. Sehingga apabila data tersebut nantinya digunakan hasilnya sesuai dengan kaidah penelitian. Pada Tabel 5 dapat dilihat hasil pengujian validitas persepsi nasabah pada tiap- tiap atribut dan Tabel 6 pengujian validitas tingkat kepentingan tiap-tiap atribut.

Nilai Corrected Item - Total Correlation juga dibandingkan dengan nilai $r$ tabel, item dinyatakan valid apabila nilai Corrected Item Total Correlation $\geq$ nilai $r$ tabel. Untuk jumlah sampel n-2 $\rightarrow$ 49-2 $=47$ dan $\alpha$ sebesar 0,05 maka nilai $r$ tabel adalah 0,282.

Reliabilitas berkenaan dengan tingkat keajegan atau ketetapan hasil pengukuran [17]. Kuesioner dikatakan reliabel jika dapat memberikan hasil relatif sama atau konsisten pada saat dilakukan pengukuran kembali pada obyek yang berlainan pada waktu yang berbeda dan memberikan hasil yang cenderung sama (tetap). Pada tabel 6 merupakan hasil pengujian reliabilitas kuesioner dengan menggunakan software SPSS.

Apabila koefisien Cronbach Alpha $\geq 0,7$ maka dapat dikatakan instrumen tersebut reliabel. Dengan demikiam, maka item-item pertanyaan tersebut dianggap reliabel dan mempunyai indeks koefisien reliabilitas yang sangat tinggi.

Pada matrik Importance Performance Analysis sumbu mendatar (X) akan diisi oleh skor tingkat kinerja atau persepsi, sedangkan sumbu tegak (Y) akan diisi oleh skor harapan atau tingkat kepentingan. Rata-rata tersebut digunakan sebagai nilai tengah pada matrik Importance Performance Analysis. Sedangkan plotting data menggunakan bantuan Software SPSS dapat dilihat pada Gambar 3.

Tabel 3. Matrik Payoff Bank X vs Bank Y

\begin{tabular}{|c|c|c|c|c|c|c|c|c|c|c|c|c|c|}
\hline & \multicolumn{11}{|c|}{$Y$} & \multirow{2}{*}{ Maximin } \\
\hline & & $\mathrm{Y}_{1}$ & $\mathrm{Y}_{2}$ & $\mathrm{Y}_{3}$ & $\mathrm{Y}_{4}$ & $Y_{5}$ & $\mathrm{Y}_{6}$ & $\mathrm{Y}_{7}$ & $\mathrm{Y}_{8}$ & $\mathrm{Y}_{9}$ & $\mathrm{Y}_{10}$ & $\mathrm{Y}_{11}$ & \\
\hline \multirow{11}{*}{$\mathrm{X}$} & $\mathrm{X}_{1}$ & 0,13 & 0,63 & 0,23 & 0,23 & 0,41 & 0,33 & 0,14 & 0,53 & 0,41 & 0,73 & 0,13 & 0,13 \\
\hline & $X_{2}$ & 0,28 & 0,78 & 0,38 & 0,38 & 0,56 & 0,48 & 0,10 & 0,68 & 0,56 & 0,88 & 0,28 & 0,1 \\
\hline & $\mathrm{X}_{3}$ & $-0,30$ & 0,20 & $-0,20$ & $-0,20$ & $-0,02$ & $-0,10$ & $-0,32$ & 0,10 & $-0,02$ & $-0,30$ & $-0,30$ & $-0,32$ \\
\hline & $\mathrm{X}_{4}$ & $-0,33$ & 0,17 & $-0,23$ & $-0,23$ & $-0,05$ & $-0,13$ & $-0,35$ & 0,07 & $-0,05$ & 0,27 & $-0,33$ & $-0,35$ \\
\hline & $\mathrm{X}_{5}$ & $-0,90$ & $-0,40$ & $-0,80$ & $-0,80$ & $-0,62$ & $-0,70$ & $-0,92$ & $-0,50$ & $-0,62$ & $-0,30$ & 0,90 & $-0,92$ \\
\hline & $\mathrm{X}_{6}$ & $-1,02$ & $-0,52$ & $-0,92$ & $-0,92$ & $-0,74$ & $-0,82$ & $-1,04$ & $-0,62$ & $-0,74$ & $-0,42$ & $-1,02$ & $-1,04$ \\
\hline & $\mathrm{X}_{7}$ & $-0,19$ & 0,31 & $-0,09$ & $-0,09$ & 0,09 & 0,01 & $-0,21$ & 0,21 & 0,09 & 0,41 & $-0,19$ & $-0,21$ \\
\hline & $\mathrm{X}_{8}$ & 0,15 & 0,65 & 0,25 & 0,25 & 0,43 & 0,35 & 0,10 & 0,55 & 0,43 & 0,75 & 0,15 & 0,1 \\
\hline & $\mathrm{X}_{9}$ & $-0,40$ & 0,10 & $-0,30$ & $-0,30$ & $-0,12$ & $-0,20$ & $-0,42$ & 0,00 & $-0,12$ & 0,20 & $-0,40$ & $-0,42$ \\
\hline & $\mathrm{X}_{10}$ & $-0,78$ & $-0,26$ & $-0,66$ & $-0,66$ & 0,48 & $-0,56$ & $-0,78$ & $-0,36$ & $-0,48$ & $-0,16$ & $-0,76$ & $-0,78$ \\
\hline & Minimax & 0,28 & 0,78 & 0,38 & 0,38 & 0,56 & 0,48 & 0,14 & 0,68 & 0,56 & 0,88 & 0,28 & \\
\hline
\end{tabular}


Tabel 4. Gap Antara Persepsi dengan Tingkat Kepentingan Atribut

\begin{tabular}{|c|c|c|c|c|c|}
\hline No & Atribut & Notasi & $\begin{array}{l}\text { Persepsi } \\
\text { (A) }\end{array}$ & $\begin{array}{l}\text { Kepentingan } \\
\text { (B) }\end{array}$ & $\begin{array}{l}\text { Gap } \\
\text { (A-B) }\end{array}$ \\
\hline 1 & Desain ATM multifungsi (setor dan tarik) & A1 & 3,18 & 4,27 & $-1,08$ \\
\hline 2 & Desain kartu kredit yang menarik & A2 & 3,51 & 3,51 & 0,00 \\
\hline 3 & Desain program yang simpel dan mudah digunakan & A3 & 3,78 & 3,98 & $-0,20$ \\
\hline 4 & $\begin{array}{l}\text { Desain ruang tunggu yang nyaman dan ketersediaan informasi (koran, } \\
\text { majalah, dll) }\end{array}$ & A4 & 3,76 & 3,96 & $-0,20$ \\
\hline 5 & Isi surat perjanjian yang jelas dan mudah dimengerti & A5 & 3,46 & 4,00 & $-0,54$ \\
\hline 6 & Jaminan keamanan informasi dan transaksi yang diberikan & A6 & 3,35 & 3,47 & $-0,12$ \\
\hline 7 & Jaminan uang sampai pada penerima dengan tepat dan cepat & A7 & 3,33 & 3,49 & $-0,16$ \\
\hline 8 & Jumlah merchant yang mendukung layanan Bank & A8 & 3,47 & 3,98 & $-0,51$ \\
\hline 9 & Kecepatan akses server yang tinggi terhadap transaksi nasabah & A9 & 3,53 & 4,14 & $-0,61$ \\
\hline 10 & Kecepatan respon admin jejaring sosial tinggi & A10 & 3,90 & 4,10 & $-0,20$ \\
\hline 11 & Kecepatan transaksi karyawan dalam melayani nasabah & A11 & 3,78 & 3,98 & $-0,20$ \\
\hline 12 & $\begin{array}{l}\text { Kemampuan karyawan (cso, teller, security) dalam menjelaskan produk } \\
\text { secara tepat }\end{array}$ & A12 & 3,76 & 4,06 & $-0,30$ \\
\hline 13 & Kemudahan akses (jual/beli) reksadana/investasi tanpa harus ke Bank & A13 & 3,61 & 3,98 & $-0,37$ \\
\hline 14 & Kemudahan memperoleh layanan (pengajuan layanan) & A14 & 3,45 & 3,57 & $-0,12$ \\
\hline 15 & $\begin{array}{l}\text { Kemudahan menghubungi perusahaan ketika terjadi pemasalahan } \\
\text { transaksi elektronik }\end{array}$ & A15 & 3,29 & 3,45 & $-0,16$ \\
\hline 16 & Kemudahan pengirman uang baik dalam negeri maupun luar negeri & A16 & 3,49 & 3,69 & $-0,20$ \\
\hline 17 & Kepedulian perusahaan membimbing nasabah dalam berinvestasi & A17 & 3,45 & 4,18 & $-0,73$ \\
\hline 18 & $\begin{array}{l}\text { Kepedulian secara individual karyawan (cso, teller, security) dalam } \\
\text { berkomunikasi dengan nasabah }\end{array}$ & A18 & 3,76 & 3,92 & $-0,16$ \\
\hline 19 & Kesesuaian informasi yang diberikan dengan kondisi dilapangan & A19 & 3,78 & 3,98 & $-0,20$ \\
\hline 20 & Kesesuaian penawaran dengan kenyataan yang diterima nasabah & A20 & 3,76 & 3,96 & $-0,20$ \\
\hline 21 & $\begin{array}{l}\text { Kesigapan karyawan (cso, teller, security) dalam menangani masalah } \\
\text { nasabah }\end{array}$ & A21 & 3,35 & 3,43 & $-0,08$ \\
\hline 22 & $\begin{array}{l}\text { Kesopanan, keramahan, dan kepedulian admin jejaring sosial dalam } \\
\text { melayani nasabah }\end{array}$ & A22 & 3,43 & 3,63 & $-0,20$ \\
\hline 23 & Ketersediaan bukti dalam setiap transaksi & A23 & 3,51 & 3,71 & $-0,20$ \\
\hline 24 & Macam-macam produk yang ditawarkan sesuai dengan kebutuhan & A24 & 3,27 & 3,47 & $-0,20$ \\
\hline 25 & Selalu update berita seputar ekonomi dan perbankan & A25 & 3,18 & 3,69 & $-0,51$ \\
\hline
\end{tabular}

Tabel 5 Hasil Uji Validitas Persepsi Atribut

\begin{tabular}{cccc}
\hline Atribut & Item & Skor Total & Ket \\
\hline A1 & Pearson Correlation &, $566^{* *}$ & Valid \\
A2 & Pearson Correlation &, $426^{*}$ & Valid \\
A3 & Pearson Correlation &, $556^{* *}$ & Valid \\
A4 & Pearson Correlation &, $649^{* *}$ & Valid \\
A5 & Pearson Correlation &, $612^{* *}$ & Valid \\
A6 & Pearson Correlation &, $302^{*}$ & Valid \\
A7 & Pearson Correlation &, $426^{*}$ & Valid \\
A8 & Pearson Correlation &, $601^{* *}$ & Valid \\
A9 & Pearson Correlation &, $408^{*}$ & Valid \\
A10 & Pearson Correlation &, $617^{* *}$ & Valid \\
A11 & Pearson Correlation &, $649^{* *}$ & Valid \\
A12 & Pearson Correlation &, $681^{* *}$ & Valid \\
A13 & Pearson Correlation &, $322^{*}$ & Valid \\
A14 & Pearson Correlation &, $387^{*}$ & Valid \\
A15 & Pearson Correlation &, $568^{* *}$ & Valid \\
A16 & Pearson Correlation &, $417^{*}$ & Valid \\
A17 & Pearson Correlation &, $552^{* *}$ & Valid \\
A18 & Pearson Correlation &, $649^{* *}$ & Valid \\
A19 & Pearson Correlation &, $612^{* *}$ & Valid \\
A20 & Pearson Correlation &, $358^{*}$ & Valid \\
A21 & Pearson Correlation &, $410^{*}$ & Valid \\
A22 & Pearson Correlation &, $582^{* *}$ & Valid \\
A23 & Pearson Correlation &, $440^{* *}$ & Valid \\
A24 & Pearson Correlation &, $572^{* *}$ & Valid \\
A25 & Pearson Correlation &, $649^{* *}$ & Valid \\
\hline & & &
\end{tabular}

Tabel 6. Hasil Uji Validitas Tingkat Kepentingan Atribut

\begin{tabular}{clcc}
\hline Atribut & Item & Skor Total & Ket \\
\hline A1 & Pearson Correlation &, $426^{* *}$ & Valid \\
A2 & Pearson Correlation &, $315^{*}$ & Valid \\
A3 & Pearson Correlation &, $521^{* *}$ & Valid \\
A4 & Pearson Correlation &, $616^{* *}$ & Valid \\
A5 & Pearson Correlation &, $404^{* *}$ & Valid \\
A6 & Pearson Correlation &, $291^{*}$ & Valid \\
A7 & Pearson Correlation &, $422^{* *}$ & Valid \\
A8 & Pearson Correlation &, $613^{* *}$ & Valid \\
A9 & Pearson Correlation &, $446^{* *}$ & Valid \\
A10 & Pearson Correlation &, $627^{* *}$ & Valid \\
A11 & Pearson Correlation &, $589^{* *}$ & Valid \\
A12 & Pearson Correlation &, $534^{* *}$ & Valid \\
A13 & Pearson Correlation &, $367^{* *}$ & Valid \\
A14 & Pearson Correlation &, $389^{* *}$ & Valid \\
A15 & Pearson Correlation &, $571^{* *}$ & Valid \\
A16 & Pearson Correlation &, $527^{* *}$ & Valid \\
A17 & Pearson Correlation &, $528^{* *}$ & Valid \\
A18 & Pearson Correlation &, $627^{* *}$ & Valid \\
A19 & Pearson Correlation &, $572^{* *}$ & Valid \\
A20 & Pearson Correlation &, $335^{*}$ & Valid \\
A21 & Pearson Correlation &, $359^{*}$ & Valid \\
A22 & Pearson Correlation &, $519^{* *}$ & Valid \\
A23 & Pearson Correlation &, $530^{* *}$ & Valid \\
A24 & Pearson Correlation &, $533^{* *}$ & Valid \\
A25 & Pearson Correlation &, $656^{* *}$ & Valid \\
\hline & & &
\end{tabular}


Tabel 7. Uji Reliabilitas Persepsi Nasabah dan Tingkat Kepentingan

\begin{tabular}{ccccc}
\hline \multirow{2}{*}{ Atribut } & \multicolumn{2}{c}{ Kepentingan } & \multicolumn{2}{c}{ Persepsi } \\
\cline { 2 - 5 } A1 & Cronbach’s Alpha & Keterangan & Cronbach's Alpha & Keterangan \\
A2 & 0,881 & Reliabel & 0,870 & Reliabel \\
A3 & 0,885 & Reliabel & 0,874 & Reliabel \\
A4 & 0,879 & Reliabel & 0,868 & Reliabel \\
A5 & 0,880 & Reliabel & 0,864 & Reliabel \\
A6 & 0,888 & Reliabel & 0,872 & Reliabel \\
A7 & 0,884 & Reliabel & 0,872 & Reliabel \\
A8 & 0,880 & Reliabel & 0,870 & Reliabel \\
A9 & 0,886 & Reliabel & 0,864 & Reliabel \\
A10 & 0,880 & Reliabel & 0,870 & Reliabel \\
A11 & 0,879 & Reliabel & 0,864 & Reliabel \\
A12 & 0,878 & Reliabel & 0,865 & Reliabel \\
A13 & 0,888 & Reliabel & 0,867 & Reliabel \\
A14 & 0,885 & Reliabel & 0,871 & Reliabel \\
A15 & 0,881 & Reliabel & 0,870 & Reliabel \\
A16 & 0,885 & Reliabel & 0,866 & Reliabel \\
A17 & 0,882 & Reliabel & 0,867 & Reliabel \\
A18 & 0,879 & Reliabel & 0,867 & Reliabel \\
A19 & 0,880 & Reliabel & 0,864 & Reliabel \\
A20 & 0,887 & Reliabel & 0,866 & Reliabel \\
A21 & 0,884 & Reliabel & 0,872 & Reliabel \\
A22 & 0,881 & Reliabel & 0,871 & Reliabel \\
A23 & 0,885 & Reliabel & 0,867 & Reliabel \\
A24 & 0,881 & Reliabel & 0,867 & Reliabel \\
A25 & 0,879 & Reliabel & 0,867 & Reliabel \\
\hline
\end{tabular}

Tabel 8. Usulan Perbaikan Peneliti

\begin{tabular}{|c|c|}
\hline Jenis Layanan & Usulan Perbaikan \\
\hline $\begin{array}{l}\text { Desain ATM } \\
\text { multifungsi (setor } \\
\text { dan tarik). }\end{array}$ & $\begin{array}{l}\text { 1. Menggunakan ATM yang mendukung setor tunai, tarik tunai, non tunai, dan cetak buku tabungan. } \\
\text { 2. Meningkatkan jaringan dan ketersediaan ATM multi fungsi sebesar 10\% (dari } 282 \text { titik menjadi } 315 \text { titik). } \\
\text { 3. Bekerjasama dengan pihak lain untuk menempatkan ATM ditempatnya. }\end{array}$ \\
\hline $\begin{array}{l}\text { Isi surat perjanjian } \\
\text { yang jelas dan } \\
\text { mudah dimengerti. }\end{array}$ & $\begin{array}{l}\text { 1. Penyederhanaan surat perjanjian, digantikan dengan modul perjanjian. } \\
\text { 2. Menggunakan aplikasi berbasis android, ios, dan blackberry untuk akses secara online. }\end{array}$ \\
\hline $\begin{array}{l}\text { Jumlah merchant } \\
\text { yang mendukung } \\
\text { layanan bank. }\end{array}$ & $\begin{array}{l}\text { 1. Bekerjasama dengan lebih banyak gerai dengan cara mendatangi lebih dulu. } \\
\text { 2. Menawarkan diskon pada pelanggan jika menggunakan transaksi dengan debit } \mathrm{Y} \text { ataupun kartu kredit } \mathrm{Y}\end{array}$ \\
\hline $\begin{array}{l}\text { Kepedulian } \\
\text { perusahaan }\end{array}$ & $\begin{array}{l}\text { 1. Mengadakan forum diskusi tentang investasi yang memungkinkan anggotanya untuk berbagi pengalaman. } \\
\text { 2. Mengadakan seminar yang berkaitan dengan investasi. }\end{array}$ \\
\hline $\begin{array}{l}\text { membimbing } \\
\text { nasabah dalam } \\
\text { berinvestasi. }\end{array}$ & $\begin{array}{l}\text { 3. Menyediakan ruang konsultasi bagi nasabah baik yang masih pemula ataupun yang sudah mahir dalam } \\
\text { membaca perekonmian. }\end{array}$ \\
\hline
\end{tabular}

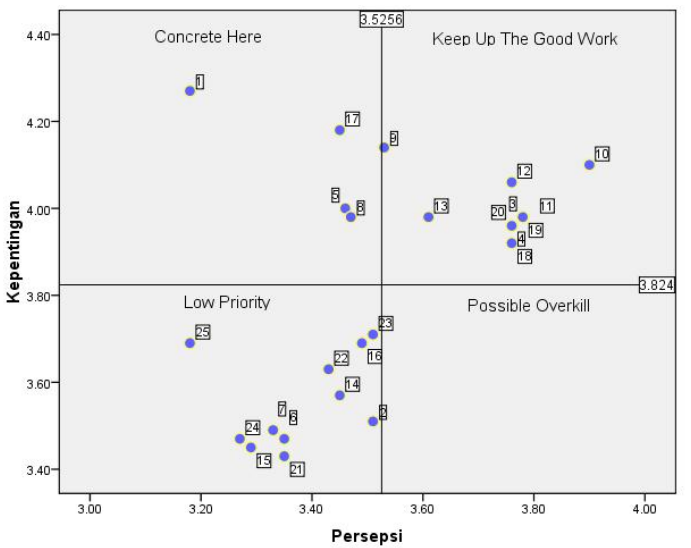

Gambar 3. Matrik Importance Performance Analysis
Secara keseluruhan, atribut Kecepatan respon admin jejaring sosial tinggi perlu dipertahankan kualitas layanannya, dan atribut Kesigapan karyawan (cso, teller, security) dalam menangani masalah nasabah perlu ditingkatkan guna meningkatkan kualitas layanan Bank Y. Sedangkan atribut Desain ATM multifungsi (setor dan tarik) menjadi prioritas utama perbaikan kualitas layanan Bank Y. Dan foukus utama perbaikan ialah pada atribut yang berada pada kuadran Concrete Here. Melihat plotting usulan perbaikan yang dapat diberikan dapat dilihat pada Tabel 8. 


\section{KESIMPULAN}

Nilai permainan pada Game Theory adalah 0,14 , artinya kemenangan bagi pemain baris. Dengan kata lain pada permainan ini dimenangkan oleh Bank X. Terdapat 4 atribut yang menjadi prioritas perbaikan yaitu: (1) Desain ATM multifungsi (setor dan tarik). (2) Isi surat perjanjian yang jelas dan mudah dimengerti. (3) Jumlah merchant yang mendukung layanan Bank. (4) Kepedulian perusahaan membimbing nasabah dalam berinvestasi. Kemudian usulan yang dapat diberikan ialah: (1) Menggunakan ATM yang mendukung setor tunai, tarik tunai, non tunai, dan cetak buku tabungan. (2) Penyederhanaan surat perjanjian, digantikan dengan modul perjanjian. (3) Bekerjasama dengan lebih banyak gerai dengan cara mendatangi lebih dulu. (4) Mengadakan forum diskusi dan seminar yang berkaitan dengan investasi.

\section{DAFTAR PUSTAKA}

[1] Kotler, Philip. Marketing management: analysis, planning, implementation, control. New Jersey:Prentice Hall, inc. 1994. ed 8.

[2] Wibowo, Danny. Dimensi Nilai Jasa Bank Terhadap Kepuasan Nasabah Dan Dampaknya Pada Loyalitas (Studi Pada Bank BCA Cabang Surabaya), Jurnal Manajemen Pemasaran. 2012. Vol. 7, No. 1, April, ISSN 1907-235X

[3] Oliver, R, L. A cognitive model of the atecedents and consquences of satisfaction decisions. Journal of marketing research. 1980. Vol XVII (November), pp.460-469

[4] Caruana, A. service loyalty: th effect of service quality and the mediating role of customer satisfaction, European journal of marketing. 2002. Vol 36 no7/8 pp 811955
[5] Aminudin. Prinsip-prinsip Riset Operasi. Jakarta:Erlangga. 2005.

[6] Tjiptono, Fandy. Manajemen Jasa. Yogyakarta:Andi. 1996.

[7] Tjiptono, Fandy. Manajemen Jasa. Yogyakarta:Andi. 2000

[8] Tjiptono, Fandy, Strategi Pemasaran. Yogyakarta:Andi. 2005. Edisi Pertama. Cetakan Pertama

[9] Tjiptono, Fandy dan Candra, Gregorius. Pemasaran Strategic. Yogyakarta:Andi 2012.

[10] Parasuraman, A., V.A., Zeithml dan L.L., Berry. SERVQUAL : A Multiple Item Scale for Meansuring Consumer Perseption of Service Quality. Jurnal of Retailing. 1998, pp 64

[11] Hasibuan, Malayu. Dasar-dasar Perbankan. Jakarta: Bumi Aksara, 2005.

[12] Djumhana, Muhamad. Hukum Perbankan di Indonesia. Bandung:Citra Aditya Bakti. 2003.

[13] Dimyati, Tjutju Tarliyah dan Dimyati, Ahmad. Operations Research ModelModel Pengambilan Keputusan. Bandung: Sinar Baru Algensindo, 2004.

[14] Ayu, Media Anugerah. Pengantar Riset Operasional. Jakarta:Gunadarma, 1996. Ed. 1. Cet. 5

[15] Sukmadinata, Nana Syaodih Metode penelitian pendidikan Bandung:Remaja Rosdakarya. 2009.

[16] Johnson, B. \& Christensen, L.. Educational Research 4th Ed.: Quantitative, qualitative, and mixmethods approaches. California: SAGE Publication. 2012.

[17] Ghozali, Imam. Aplikasi Analisis Multivariate Dengan Program SPSS. Semarang:Universitas Diponegoro. 2009. Edisi Keempat. 